\title{
Enzymatic Analysis of Tet Proteins: Key Enzymes in the Metabolism of DNA Methylation
}

\author{
Li Shen ${ }^{*}, \dagger$ and Yi Zhang ${ }^{*}, \dagger, 1$ \\ "Howard Hughes Medical Institute \\ tDepartment of Biochemistry and Biophysics, Lineberger Comprehensive Cancer Center, \\ University of North Carolina at Chapel Hill, Chapel Hill, North Carolina, USA
}

\section{Abstract}

One of the most exciting recent advances in the epigenetic field is the discovery that 5methylcytosine $(5 \mathrm{mC})$ in DNA can be iteratively oxidized by a family of proteins known as Tet proteins to generate 5-hydroxymethylcytosine $(5 \mathrm{hmC}), 5$-formylcytosine $(5 \mathrm{fC})$, and 5carboxylcytosine $(5 \mathrm{caC})$. These $5 \mathrm{mC}$ derivatives can be further processed by thymine-DNA glycosylase (TDG) followed by base excision repair or by replication-dependent dilution leading to DNA demethylation. Given the similarity between $5 \mathrm{mC}$ and its oxidation derivatives, many of the conventional techniques used for $5 \mathrm{mC}$ analysis cannot distinguish between $5 \mathrm{mC}$ and $5 \mathrm{hmC} /$ $5 \mathrm{fC} / 5 \mathrm{caC}$. Here, we describe 2D-TLC and mass spectrometry methods that we have successfully used in differentiating $5 \mathrm{mC}$ from its oxidative derivatives as well as in characterizing the enzymatic activity of Tet proteins both in vitro and in vivo.

\section{INTRODUCTION}

\begin{abstract}
One of the recent advances in the epigenetic filed is the discovery that Tet family proteins are capable of catalyzing the oxidation of 5-methylcytosine $(5 \mathrm{mC})$, a well-characterized epigenetic mark, into 5-hydroxymethylcytosine $(5 \mathrm{hmC}$ ) in mammalian DNA (Ito et al., 2010; Tahiliani et al., 2009). Remarkably, more recent studies have shown that $5 \mathrm{hmC}$ can be further oxidized by Tet proteins to generate 5-formylcytosine (5fC) and 5-carboxylcytosine (5caC) (He et al., 2011; Ito et al., 2011), which have also been detected in the mouse genome (Ito et al., 2011; Pfaffeneder et al., 2011). These new findings suggest that Tet protein-catalyzed iterative oxidation of $5 \mathrm{mC}$ could be the initial steps in DNA demethylation pathways (Fig. 5.1). Indeed, immunostaining of the zygotic DNA have shown that loss of $5 \mathrm{mC}$ in the male pronucleus correlates with the appearance of $5 \mathrm{hmC}, 5 \mathrm{fC}$, and $5 \mathrm{caC}$ ( Gu et al., 2011; Inoue, Shen, Dai, He, \& Zhang, 2011; Inoue \& Zhang, 2011; Iqbal, Jin, Pfeifer, \& Szabo, 2011; Wossidlo et al., 2011), which are gradually diluted in a replication-dependent manner during mouse preimplantation development (Inoue et al., 2011; Inoue \& Zhang, 2011). In addition to this passive demethylation process, both $5 \mathrm{fC}$ and $5 \mathrm{caC}$, but not $5 \mathrm{mC}$ and $5 \mathrm{hmC}$, can be actively removed from the genome by thymine-DNA glycosylase (TDG) through a base excision repair pathway (He et al., 2011; Maiti \& Drohat, 2011). Thus, Tetmediated iterative oxidation of $5 \mathrm{mC}$ plays an important role in regulating DNA methylation dynamics.
\end{abstract}

However, conventional approaches for DNA methylation studies, including bisulfite genomic sequencing and methylation-sensitive restriction enzyme digestion, cannot

(C) 2012 Elsevier Inc. All rights reserved.

${ }^{1}$ Corresponding author: yi_zhang@med.unc.edu. 
discriminate $5 \mathrm{mC}$ from other $5 \mathrm{mC}$ oxidation products such as $5 \mathrm{hmC}$ (Huang et al., 2010; Jin, Kadam, \& Pfeifer, 2010). It was also reported that $5 \mathrm{fC}$ and $5 \mathrm{caC}$ are interpreted as unmodified $\mathrm{C}$ in bisulfite genomic sequencing (Booth et al., 2012; He et al., 2011). To overcome these technical difficulties and to study Tet-mediated iterative oxidation, several techniques have been developed which allow quantification and genome-wide mapping of the cytosine derivatives. These techniques include (1) thin-layer chromatography (TLC) analysis of modified nucleotides (Ito et al., 2010; Kriaucionis \& Heintz, 2009; Tahiliani et al., 2009), (2) liquid chromatography and mass spectrometry (LC-MS) analysis (Globisch et al., 2010; Ito et al., 2011; Munzel et al., 2010), (3) cytosine modification-specific antibodies (Ficz et al., 2011; Williams et al., 2011; Wu et al., 2011), (4) glucosylation of 5hmC (Kinney et al., 2011; Szwagierczak, Bultmann, Schmidt, Spada, \& Leonhardt, 2010), (5) chemical/enzymatic labeling or conversion of modified cytosine (Booth et al., 2012; Pastor et al., 2011; Song, Szulwach, et al., 2011; Yu et al., 2012), and (6) single-molecule, realtime sequencing (Flusberg et al., 2010; Song, Clark, et al., 2011).

Here, we describe two methods that we have been using in studying the Tet enzymatic activity. The 2D-TLC method is easy to follow and does not require additional instruments, while the mass spectrometry method is more accurate and sensitive and can be used to quantify the levels of cytosine derivatives in genomic DNA.

\section{EXPRESSION AND PURIFICATION OF TET PROTEINS}

For production of recombinant proteins, cDNAs encoding the catalytic domains of mouse Tet1 (aa1367-2039), Tet2 (aa916-1921), Tet3 (aa697-1668), and their corresponding catalytic mutants (Ito et al., 2010) are cloned into a modified pFastBac-HTb (Invitrogen) insect cell expression vector inframe with a FLAG tag at the N-terminus. Constructs are transformed into DH10Bac Escherichia coli (Invitrogen) following manufacturer's instructions to generate bacmid DNA. Since recombinant bacmid DNA is $\geq 135 \mathrm{kbp}$, most silica-gel-membrane-based plasmid miniprep kits are not suitable for bacmid DNA isolation, anion-exchange-resin-based kits should be used instead (e.g., PureLink HiPure Plasmid Miniprep Kit (Invitrogen)). Alternatively, we found that crude purification of bacmid DNA using conventional alkaline lysis followed by ethanol precipitation could also give satisfying results in the subsequent Sf9 cell transfections. To verify the successful transposition of Tet cDNAs to bacmid DNA, polymerase chain reaction (PCR) analysis is performed with pUC/ M13 forward (5' ${ }^{\prime}$-CCCAGTCACGACGTTGTAAAACG-3') and reverse (5' AGCGGATAACAATTTCACACAGG-3') primers. A PCR band of $2400 \mathrm{bp}+$ the size of the insert indicates successful transposition, otherwise, an $\sim 350 \mathrm{bp}$ band will show up. Once correct bacmid DNA is generated, baculovirus can be produced in Sf9 cells.

Sf9 cells are maintained at a density of $0.5-6 \times 10^{6}$ cells $/ \mathrm{ml}$ in Sf-900 II SFM medium (Invitrogen) containing $10 \%$ fetal bovine serum in a spinner flask at $27{ }^{\circ} \mathrm{C}$. Before transfection, cells are seeded in a six-well plate with $9 \times 10^{5}$ cells/well and allowed to attach for $1 \mathrm{~h}$ at $27^{\circ} \mathrm{C}$. Dilute $1 \mu \mathrm{g}$ of bacmid DNA (or the amount from $100 \mu \mathrm{l}$ of bacteria if crude bacmid DNA is used) and $8 \mu l$ of Cellfectin II (Invitrogen) separately with $100 \mu l$ of Grace's Insect Medium (unsupplemented). Combine the diluted bacmid with diluted Cellfectin II reagent and incubate at room temperature for $30 \mathrm{~min}$. While the transfection complexes are forming, remove the medium from the plate and wash cells once with $2 \mathrm{ml}$ of Grace's Insect Medium (unsupplemented). Remove the wash medium, add $800 \mu 1$ of Grace's Insect Medium (unsupplemented) to the transfection mixture and gently add the mixture onto the cells immediately. Incubate cells for $5 \mathrm{~h}$ at $27^{\circ} \mathrm{C}$ before replacing the transfection mixture with $2 \mathrm{ml}$ of complete growth medium (Sf-900 II SFM medium containing $10 \%$ fetal bovine serum). After $96 \mathrm{~h}$, collect the medium and centrifuge at $500 \times g$ for 5 min to remove floating cells. Transfer the supernatant containing baculovirus to a new 
tube and store the $\mathrm{P} 1$ viral stock at $4{ }^{\circ} \mathrm{C}$ protected from light. To verify the successful production of virus, expression of recombinant Tet proteins in the transfected cells can be examined by Western blot, although the expression may be weak at this stage. To amplify the P1 viral stock, seed $2 \times 10^{6}$ cells/well in a six-well plate, add $50 \mu \mathrm{l}$ of P1 viral stock, and incubate for $72 \mathrm{~h}$. Collect the P2 viral stock as per the P1 stock. We usually further amplify the $\mathrm{P} 2$ viral stock to generate $\mathrm{P} 3$ viral stock of higher titer. Seed $9 \times 10^{6}$ cells $/$ dish in a $10 \mathrm{~cm}$ dish, add $250 \mu \mathrm{l}$ of P2 viral stock, and incubate for $72 \mathrm{~h}$. The titer of the P3 viral stock is usually $\sim 2 \times 10^{8} \mathrm{pfu} / \mathrm{ml}$.

To express the Tet proteins, prepare 11 of Sf9 cells in mid log growth phase $\left(1.5-2 \times 10^{6}\right.$ cells/ml) in a spinner flask, infect the cells with $20 \mathrm{ml} \mathrm{P} 3$ viral stock (the multiplicity of infection (MOI) is $\sim 2$ ) for $72 \mathrm{~h}$. Cells are collected and washed once with ice-cold phosphate buffered saline. Cell pellet is then resuspended in $40 \mathrm{ml}$ of LysisBuffer F (50 mM HEPES, $500 \mathrm{~m} M \mathrm{NaCl}, 2 \mathrm{~m} M \mathrm{MgCl}_{2}, 2 \mathrm{~m} M$ DTT, $0.2 \%$ NP-40, 20\% glycerol, $1 \times$ protease inhibitors without EDTA (Roche), pH 8.0) and transferred to a Dounce homogenizer with a type A pestle. Homogenize slowly for 30 times over a 30-min period on ice and centrifuge the cell lysate at $14,000 \times g$ for $20 \mathrm{~min}$ at $4{ }^{\circ} \mathrm{C}$. While centrifuging the cell lysate, wash $1 \mathrm{ml}$ of $50 \%$ slurry of FLAG M2 beads (Sigma) with $20 \mathrm{ml}$ Lysis Buffer F in a $50 \mathrm{ml}$ conical tube, spin at $500 \times g$ for $5 \mathrm{~min}$, remove the supernatant. Transfer the supernatant of the cell lysate to the tube and rotate at $4{ }^{\circ} \mathrm{C}$ for $3 \mathrm{~h}$. After the incubation, collect beads by spinning at $500 \times g$ for 5 min at $4{ }^{\circ} \mathrm{C}$, wash beads with $30 \mathrm{ml}$ Wash Buffer (50 m $M$ HEPES, $150 \mathrm{~m} M \mathrm{NaCl}, 2 \mathrm{~m} M$ $\mathrm{MgCl}_{2}, 1 \mathrm{~m} M$ DTT, $20 \%$ glycerol) for three times, and elute the protein with $500 \mu \mathrm{l}$ Wash Buffer containing $200 \mu \mathrm{g} / \mathrm{ml} 3 \times$ FLAG peptide (Sigma) by rotating at $4{ }^{\circ} \mathrm{C}$ for $30 \mathrm{~min}$. Aliquot the eluted protein and store at $-80^{\circ} \mathrm{C}$. The purity of the eluted protein can be determined by Coomassie staining of an SDS-PAGE.

\section{TET ACTIVITY ASSAYS}

\subsection{Preparation of the substrates}

To set up the in vitro enzymatic assays, proper DNA substrates are required. If the reaction products are to be analyzed by TLC assay, the modified cytosine should be placed in the context of a restriction site that can be digested regardless of the modification. Since TaqI (with a recognition site of TCGA) is insensitive to all cytosine modifications (Ito et al., 2011), we have been using double-stranded 20-mer DNA containing a TaqI site as our substrate with the following sequences:

$$
\begin{aligned}
& \text { Taq20-F: 5' -GTTCAGCTTXGATCACGCTC-3' } \\
& \text { Taq20-R: 5' -GAGCGTGATXGAAGCTGAAC-3' }
\end{aligned}
$$

( $\mathrm{X}$ represents a modified cytosine)

However, if mass spectrometry is to be used as the detection method, the modified cytosine can be placed anywhere in the strand. Besides the above 20-mer DNA, we have also been using a double-stranded 38-mer DNA containing nine modified cytosines in each strand as in natural situation where the modified cytosines might be clustered together:

\section{8mer-F: 5' -AGCCXGXGCXGXGCXGGTXGAGXGGCXGCT CCXGCAGC-3' \\ 38mer-R: 5'-GCTGCXGGAGCXGCCXCTCXACCXGCXCXGC XCXGGCT-3'}

Oligonucleotides containing $5 \mathrm{mC}$ and $5 \mathrm{hmC}$ can be directly purchased from Integrated DNA Technologies, while those containing $5 \mathrm{fC}$ and $5 \mathrm{caC}$ are synthesized as described (Dai $\& \mathrm{He}, 2011)$. However, the phosphoramidite forms of both $5 \mathrm{fC}$ and $5 \mathrm{caC}$ have become commercially available recently from Glen Research. Therefore, oligonucleotides containing $5 \mathrm{fC}$ and $5 \mathrm{caC}$ can now be synthesized in most oligonucleotide synthesis facilities. 
After synthesis of the oligonucleotides containing the desired modification, the oligonucleotides are annealed in $1 \times \mathrm{NEB}$ Buffer 2 by boiling the mixture for $5 \mathrm{~min}$ and slowly cooling down to room temperature. High-quality double-stranded DNA can be further purified by polyacrylamide gel electrophoresis if necessary.

\subsection{In vitro enzymatic assays}

For in vitro enzymatic activity assays, $0.5 \mu \mathrm{g}$ of various double-stranded DNA substrates are incubated with $1.2 \mu \mathrm{g}$ of wild-type or catalytic mutant Tet proteins ( 1:6 enzyme/substrate ratio if the 20-mer substrate is used; $50 \mu l$ reaction) in the presence of $50 \mathrm{~m} M$ HEPES (pH 7.9), $100 \mathrm{~m} M \mathrm{NaCl}, 75 \mu M \mathrm{Fe}\left(\mathrm{NH}_{4}\right)_{2}\left(\mathrm{SO}_{4}\right)_{2}, 2 \mathrm{~m} M$ ascorbate, $1 \mathrm{~m} M$ a-ketoglutarate (2oxoglutarate), $1 \mathrm{mM}$ DTT and $1 \mathrm{mM}$ ATP at $37^{\circ} \mathrm{C}$ for $40 \mathrm{~min}$. Since Tet proteins are quickly inactivated under the reaction condition, it is necessary to shorten the incubation time to $2.5 \mathrm{~min}$ if kinetic studies are to be performed (Ito et al., 2011). The reactions are stopped by the addition of 10 volumes of ice-cold Buffer PN (QIAGEN), and the oligonucleotides are then purified using QIAquick Nucleotide Removal Kit (QIAGEN) following manufacturer's instructions. Now, the oligonucleotides are ready to be analyzed by either 2D-TLC or mass spectrometry.

\subsection{In vivo enzymatic assays in HEK293T cells}

HEK293T cells contain low levels of endogenous 5hmC, 5fC, and 5caC. Since high transfection efficiency (>90\%) and high Tet protein expression can be achieved in HEK293T cells, it provides an ideal system for analyzing enzymatic activity of Tet proteins in vivo. To overexpress Tet proteins in HEK293T cells, cDNAs encoding the full-length or catalytic domains of mouse Tet proteins and their corresponding catalytic mutants are cloned into a modified pcDNA3 (Invitrogen) mammalian cell expression vector in-frame with a FLAG tag at the N-terminus. $8 \times 10^{5}$ cells/well are seeded into a six-well plate on the day before transfection. The cells are transfected with $2 \mu \mathrm{g}$ of Tet expression constructs with FuGENE HD (Roche; 1:3 plasmid/FuGENE HD ratio) following manufacturer's instructions. $48 \mathrm{~h}$ after transfection, the transfected cells are harvested and genomic DNA is extracted using a DNeasy Blood \& Tissue Kit (QIAGEN; include the optional RNase A treatment step during genomic DNA extraction and elute with Buffer EB). The genomic DNA is now ready to be analyzed by either 2D-TLC or mass spectrometry.

\section{ANALYSIS OF THE CYTOSINE DERIVATIVES BY 2D-TLC}

TLC is a classic method that separates different nucleotides based on their differential migration rates on TLC plates. TLC assays have been used successfully for analyzing $5 \mathrm{hmC}$ in previous studies (Koh et al., 2011; Kriaucionis \& Heintz, 2009; Tahiliani et al., 2009). However, under previous TLC conditions, $5 \mathrm{hmC}$ and $5 \mathrm{fC}$ have almost identical migration patterns, and $5 \mathrm{caC}$ fails to migrate (Ito et al., 2011). To overcome this technical problem, we developed a modified 2D-TLC assay using a more acidic buffer as the second developing condition. For 2D-TLC analysis, the in vitro enzymatic reaction products (or $10 \mu \mathrm{g}$ of genomic DNA) are digested with $40 \mathrm{U}$ of TaqI (use $100 \mathrm{U}$ for genomic DNA) overnight, and then $20 \mathrm{U}$ of calf intestinal alkaline phosphatase (CIAP) are added, followed by two more hours of incubation. The digested DNA is purified with QIAquick Nucleotide Removal kit. The DNA is then endlabeled with $40 \mathrm{U}$ of T4 polynucleotide kinase and 15 $\mu \mathrm{Ci}$ of $\left[\gamma^{-32} \mathrm{P}\right]$-ATP $(25 \mathrm{Ci} / \mathrm{mmol})$ for $1 \mathrm{~h}$, ethanol-precipitated, and redissolved in $40 \mu \mathrm{l}$ of water. Then, the labeled DNA is heat-denatured and digested into nucleotides with $200 \mathrm{U}$ of nuclease $\mathrm{S} 1$ (Sigma) in the presence of $0.5 \mathrm{mMZnSO}_{4}, 14 \mathrm{~m} M$ sodium acetate (pH 5.2) at $37^{\circ} \mathrm{C}$ for $2 \mathrm{~h}$ (total volume is $50 \mu \mathrm{l}$ ) before being analyzed by $2 \mathrm{D}-\mathrm{TLC}$. 
For 2D-TLC assay, $1.5 \mu \mathrm{l}$ of the digestion product is spotted on one corner of a $20 \times 20 \mathrm{~cm}$ Polyethyleneimine cellulose F TLC plate (Merck), and the TLC plate is developed using TLC Buffer 1 (isobutyric acid: $\mathrm{NH}_{4} \mathrm{OH}: \mathrm{H}_{2} \mathrm{O}=66: 2: 20$ ). After complete drying, the TLC plate is developed in the second direction using TLC Buffer 2 (isopropanol: $\mathrm{HCl}: \mathrm{H}_{2} \mathrm{O}$ 70:15:15). After drying, the TLC plate is exposed to an X-ray film for autoradiography or a storage phosphor screen for better quantitation. A representative 2D-TLC assay result is shown in Fig. 5.2. To confirm the migration patterns of the cytosine derivatives, standard nucleosides (Berry \& Associates) can be labeled with deoxycytidine kinase (Proteinkinase.de) in the presence of $\left[\gamma^{32} \mathrm{P}\right]$-ATP and analyzed in parallel with the samples using the same 2D-TLC procedure.

\section{ANALYSIS OF THE CYTOSINE DERIVATIVES BY MASS SPECTROMETRY}

For quantitative analysis of the cytosine derivatives, we developed a sensitive and specific method using liquid chromatography-tandem mass spectrometry (LC-MS/MS) with multiple reactions monitoring (MRM) to simultaneously detect and quantitate cytosine derivatives (Ito et al., 2011). The instrument we have been using is an ultra-performance liquid chromatography system (Waters) coupled to a TSQ-Quantum Ultra triple-quadrupole mass analyzer (ThermoFinnigan) with a heat-assisted electrospray ionization source, which can detect and quantitate as low as $10 \mathrm{fmol}$ of cytosine derivatives (Fig. 5.3A).

To prepare the samples, in vitro enzymatic reaction products or $2.5 \mu \mathrm{g}$ of genomic DNA are heat-denatured, hydrolyzed with $90 \mathrm{U}$ of nuclease $\mathrm{S} 1$ in Buffer $1\left(0.5 \mathrm{~m} M \mathrm{ZnSO}_{4}, 14 \mathrm{~m} M\right.$ sodium acetate, $\mathrm{pH} 5.2$ ) at $37^{\circ} \mathrm{C}$ for at least $1 \mathrm{~h}$ (total volume is $44.5 \mu \mathrm{l}$ ), followed by the addition of $5 \mu \mathrm{l} 10 \times$ Buffer 2 ( $560 \mathrm{~m} M$ Tris- $\mathrm{HCl}, 30 \mathrm{~m} M \mathrm{NaCl}, 10 \mathrm{~m} M \mathrm{MgCl}_{2}, \mathrm{pH} 8.3$ ), 0.5 $\mu \mathrm{g}$ of phosphodiesterase I and $2 \mathrm{U}$ of CIAP for an additional $1 \mathrm{~h}$ (final volume is $50 \mu \mathrm{l}$ ). Then, the digested DNA is filtered with Nanosep3K to remove enzymes and undigested DNA (if any). For the in vitro enzymatic reaction products, dilute the samples to $200 \mu \mathrm{l}$, and subject $10 \mu \mathrm{l}$ of the diluted samples to LC-MS/MS analysis. For genomic DNA, directly subject $10 \mu \mathrm{l}$ of the filtered samples to LC-MS/MS analysis.

Separation prior to mass spectrometry is achieved using a $2.1 \times 100 \mathrm{~mm}$ HSS T3 $1.8 \mu \mathrm{m}$ column (Waters) with gradient elution at a flow rate of $0.2 \mathrm{ml} / \mathrm{min}$ using $0.02 \%$ acetic acid in water as mobile phase $\mathrm{A}$ and methanol as mobile phase $\mathrm{B}$. The gradient is $0 \rightarrow 3.5 \mathrm{~min}$, $3 \% \mathrm{~B}, 3.5 \rightarrow 12.5 \mathrm{~min}, 3 \% \rightarrow 16.2 \% \mathrm{~B}, 12.5 \rightarrow 13 \mathrm{~min}, 16.2 \% \rightarrow 30 \% \mathrm{~B}, 13 \rightarrow 15 \mathrm{~min}, 30 \% \mathrm{~B}$, $15 \rightarrow 16 \mathrm{~min}, 30 \% \rightarrow 3 \% \mathrm{~B}, 16 \rightarrow 20 \mathrm{~min}, 3 \% \mathrm{~B}$. The mass spectrometer is set to positive mode, precursor to product ion transitions for cytosine and its derivatives are monitored using the parameters in Tables 5.1 and 5.2. External standard calibration is used for the quantitation. To correct for matrix effects, the calibration curves for nucleoside standards (Berry \& Associates) are generated by mixing the nucleosides with the enzymes in the digestion buffer and then filtered using the same procedures used for the samples. Calibration curves are constructed for each batch of analysis. It is also important to include one standard sample every 10 samples to check the signal stability of the instrument.

\section{ANALYSIS OF THE ENDOGENOUS LEVEL OF CYTOSINE DERIVATIVES BY MASS SPECTROMETRY}

For endogenous $5 \mathrm{fC}$ and $5 \mathrm{caC}$ in genomic DNA, they are first enriched by HPLC fractionation before being analyzed by mass spectrometry (Fig. 5.3B and C) (Ito et al., 2011). Before analyzing genomic DNA, the retention time for each of the cytosine derivatives needs to be determined using standard nucleosides (Fig. 5.3C). We have noticed that the retention time of $5 \mathrm{caC}$ is sensitive to $\mathrm{pH}$ of the digestion buffer and the mobile phase, thus the standard nucleosides should be prepared in the sample digestion buffer 
before HPLC analysis, and the $\mathrm{pH}$ of mobile phase A should also be accurately adjusted. To avoid carry-over of the standard nucleosides, it is necessary to make several blank injections before sample analysis. We also include the fractions from the last blank injection in the subsequent LC-MS/MS analysis to make sure there is no carry-over.

To enrich 5fC and 5caC, 20-100 $\mu \mathrm{g}$ of genomic DNA is heat-denatured, hydrolyzed with

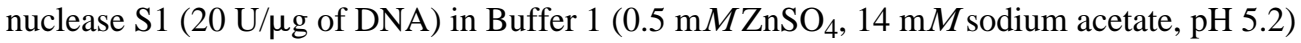
at $37{ }^{\circ} \mathrm{C}$ for at least $1 \mathrm{~h}$ (total volume is $250 \mu \mathrm{l}$ ), followed by the addition of $30 \mu \mathrm{l} 10 \mathrm{x}$ Buffer 2 (560 $\mathrm{m} M$ Tris-HCl, $30 \mathrm{~m} M \mathrm{NaCl}, 10 \mathrm{~m} M \mathrm{MgCl}_{2}$, pH 8.3), $5 \mu \mathrm{g}$ of phosphodiesterase I and $20 \mathrm{U}$ of CIAP for an additional $1 \mathrm{~h}$ (final volume is $300 \mu \mathrm{l}$ ), and filtered with Nanosep3K to remove enzymes and undigested DNA (if any). Then, $275 \mu 1$ of the filtered samples are subjected to HPLC (Agilent 1200 with a $4.6 \times 150 \mathrm{~mm}, 3 \mu \mathrm{m}$, Atlantis T3 column) with gradient elution at a flow rate of $0.8 \mathrm{ml} / \mathrm{min}$ using $5 \mathrm{mM}$ ammonium formate in water $(\mathrm{pH} 4.0)$ as mobile phase $\mathrm{A}$ and methanol as mobile phase B. The gradient is $0 \rightarrow 15 \mathrm{~min}, 3 \% \rightarrow 30 \% \mathrm{~B}, 15 \rightarrow 17 \mathrm{~min}, 30 \% \mathrm{~B}, 17 \rightarrow 18 \mathrm{~min}, 30 \% \rightarrow 3 \% \mathrm{~B}$, $18 \rightarrow 25 \mathrm{~min}, 3 \% \mathrm{~B}$. During the HPLC separation, fractions corresponding to the retention time of $5 \mathrm{hmC}, 5 \mathrm{fC}$, and $5 \mathrm{caC}$ are collected for LC-MS/MS quantitation, while $\mathrm{C}$ and $5 \mathrm{mC}$ are directly quantitated with external standard curves using the UV detector signals (Fig. 5.3C). The collected fractions are then dried with a Speed-Vac and redissolved with $20 \mu \mathrm{l}$ of water. Of which, $15 \mu \mathrm{l}$ is subjected to LC-MS/MS analysis as described above. External standard calibration is used for the quantitation. We suggest make new calibration curve for each batch of analysis and include one standard for every 10 samples to confirm the signal stability of the instrument.

Considering the sample loss during sample enrichment, the recovery rates of $5 \mathrm{hmC}, 5 \mathrm{fC}$, and $5 \mathrm{caC}$ need to be determined and used to correct the percentages of the cytosine derivatives in total cytosines. To determine the recovery rates, standard $5 \mathrm{hmC}, 5 \mathrm{fC}$, and $5 \mathrm{caC}$ nucleosides are mixed at five different levels with $15 \mathrm{nmol}$ (if $20 \mu \mathrm{g}$ of genomic DNA is analyzed) each of C, G, T, A in the digestion buffer, then the standard mixtures are analyzed by the same procedures as that used for genomic DNA samples. Finally, measured percentages (cytosine derivative/total cytosine) in the standard mixtures are plotted against the actual percentages. The recovery rates determined are usually $\sim 50 \%$ for all the cytosine derivatives and can be used to correct the measured results for genomic DNA samples.

\section{Acknowledgments}

We thank Dr. James A. Swenberg and Leonard B. Collins (UNC) for their help in the development of the mass spectrometry method. Y. Z. is a HHMI Investigator. This work was supported by NIH (GM68804 and U01DK089565) and the HHMI.

\section{REFERENCSE}

Booth MJ, Branco MR, Ficz G, Oxley D, Krueger F, Reik W, Balasubramanian S. Quantitative sequencing of 5-methylcytosine and 5-hydroxymethylcytosine at single-base resolution. Science. 2012; 336:934-937. [PubMed: 22539555]

Dai Q, He C. Syntheses of 5-formyl- and 5-carboxyl-dC containing DNA oligos as potential oxidation products of 5-hydroxymethylcytosine in DNA. Organic Letters. 2011; 13:3446-3449. [PubMed: 21648398]

Ficz G, Branco MR, Seisenberger S, Santos F, Krueger F, Hore TA, et al. Dynamic regulation of 5hydroxymethylcytosine in mouse ES cells and during differentiation. Nature. 2011; 473:398-402. [PubMed: 21460836]

Flusberg BA, Webster DR, Lee JH, Travers KJ, Olivares EC, Clark TA, et al. Direct detection of DNA methylation during single-molecule, real-time sequencing. Nature Methods. 2010; 7:461-465. [PubMed: 20453866] 
Globisch D, Munzel M, Muller M, Michalakis S, Wagner M, Koch S, et al. Tissue distribution of 5hydroxymethylcytosine and search for active demethylation intermediates. PLos One. 2010; 5:e15367. [PubMed: 21203455]

Gu TP, Guo F, Yang H, Wu HP, Xu GF, Liu W, et al. The role of Tet3 DNA dioxygenase in epigenetic reprogramming by oocytes. Nature. 2011; 477:606-610. [PubMed: 21892189]

He YF, Li BZ, Li Z, Liu P, Wang Y, Tang Q, et al. Tet-mediated formation of 5-carboxylcytosine and its excision by TDG in mammalian DNA. Science. 2011; 333:1303-1307. [PubMed: 21817016]

Huang Y, Pastor WA, Shen Y, Tahiliani M, Liu DR, Rao A. The behaviour of 5hydroxymethylcytosine in bisulfite sequencing. PloS One. 2010; 5:e8888. [PubMed: 20126651]

Inoue A, Shen L, Dai Q, He C, Zhang Y. Generation and replication-dependent dilution of $5 \mathrm{fC}$ and 5caC during mouse preimplantation development. Cell Research. 2011; 21:1670-1676. [PubMed: 22124233]

Inoue A, Zhang Y. Replication-dependent loss of 5-hydroxymethylcytosine in mouse preimplantation embryos. Science. 2011; 334:194. [PubMed: 21940858]

Iqbal K, Jin SG, Pfeifer GP, Szabo PE. Reprogramming of the paternal genome upon fertilization involves genome-wide oxidation of 5-methylcytosine. Proceedings of the National Academy of Sciences of the United States of America. 2011; 108:3642-3647. [PubMed: 21321204]

Ito S, D'Alessio AC, Taranova OV, Hong K, Sowers LC, Zhang Y. Role of Tet proteins in $5 \mathrm{mC}$ to 5hmC conversion, ES-cell self-renewal and inner cell mass specification. Nature. 2010; 466:11291133. [PubMed: 20639862]

Ito S, Shen L, Dai Q, Wu SC, Collins LB, Swenberg JA, et al. Tet proteins can convert 5methylcytosine to 5-formylcytosine and 5-carboxylcytosine. Science. 2011; 333:1300-1303. [PubMed: 21778364]

Jin SG, Kadam S, Pfeifer GP. Examination of the specificity of DNA methylation profiling techniques towards 5-methylcytosine and 5-hydroxymethylcytosine. Nucleic Acids Research. 2010; 38:e125. [PubMed: 20371518]

Kinney SM, Chin HG, Vaisvila R, Bitinaite J, Zheng Y, Esteve PO, et al. Tissue-specific distribution and dynamic changes of 5-hydroxymethylcytosine in mammalian genomes. The Journal of Biological Chemistry. 2011; 286:24685-24693. [PubMed: 21610077]

Koh KP, Yabuuchi A, Rao S, Huang Y, Cunniff K, Nardone J, et al. Tet1 and Tet2 regulate 5hydroxymethylcytosine production and cell lineage specification in mouse embryonic stem cells. Cell Stem Cell. 2011; 8:200-213. [PubMed: 21295276]

Kriaucionis S, Heintz N. The nuclear DNA base 5-hydroxymethylcytosine is present in Purkinje neurons and the brain. Science. 2009; 324:929-930. [PubMed: 19372393]

Maiti A, Drohat AC. Thymine DNA glycosylase can rapidly excise 5-formylcytosine and 5carboxylcytosine: Potential implications for active demethylation of $\mathrm{CpG}$ sites. The Journal of Biological Chemistry. 2011; 286:35334-35338. [PubMed: 21862836]

Munzel M, Globisch D, Bruckl T, Wagner M, Welzmiller V, Michalakis S, et al. Quantification of the sixth DNA base hydroxymethylcytosine in the brain. Angewandte Chemie (International Ed. in English). 2010; 49:5375-5377. [PubMed: 20583021]

Pastor WA, Pape UJ, Huang Y, Henderson HR, Lister R, Ko M, et al. Genome-wide mapping of 5hydroxymethylcytosine in embryonic stem cells. Nature. 2011; 473:394-397. [PubMed: 21552279]

Pfaffeneder T, Hackner B, Truss M, Munzel M, Muller M, Deiml CA, et al. The discovery of 5formylcytosine in embryonic stem cell DNA. Angewandte Chemie (International Ed. in English). 2011; 50:7008-7012. [PubMed: 21721093]

Song CX, Clark TA, Lu XY, Kislyuk A, Dai Q, Turner SW, et al. Sensitive and specific singlemolecule sequencing of 5-hydroxymethylcytosine. Nature Methods. 2011; 9:75-77. [PubMed: 22101853]

Song CX, Szulwach KE, Fu Y, Dai Q, Yi C, Li X, et al. Selective chemical labeling reveals the genome-wide distribution of 5-hydroxymethylcytosine. Nature Biotechnology. 2011; 29:68-72.

Szwagierczak A, Bultmann S, Schmidt CS, Spada F, Leonhardt H. Sensitive enzymatic quantification of 5-hydroxymethylcytosine in genomic DNA. Nucleic Acids Research. 2010; 38:e181. [PubMed: 20685817] 
Tahiliani M, Koh KP, Shen Y, Pastor WA, Bandukwala H, Brudno Y, et al. Conversion of 5methylcytosine to 5-hydroxymethylcytosine in mammalian DNA by MLL partner TET1. Science. 2009; 324:930-935. [PubMed: 19372391]

Yu M, Hon GC, Szulwach KE, Song CX, Zhang L, Kim A, Li X, Dai Q, Shen Y, Park B, et al. Baseresolution analysis of 5-hydroxymethylcytosine in the Mammalian genome. Cell. 2012; 149:13681380. [PubMed: 22608086]

Williams K, Christensen J, Pedersen MT, Johansen JV, Cloos PA, Rappsilber J, et al. TET1 and hydroxymethylcytosine in transcription and DNA methylation fidelity. Nature. 2011; 473:343348. [PubMed: 21490601]

Wossidlo M, Nakamura T, Lepikhov K, Marques CJ, Zakhartchenko V, Boiani M, et al. 5Hydroxymethylcytosine in the mammalian zygote is linked with epigenetic reprogramming. Nature Communications. 2011; 2:241.

Wu H, D'Alessio AC, Ito S, Wang Z, Cui K, Zhao K, et al. Genome-wide analysis of 5hydroxymethylcytosine distribution reveals its dual function in transcriptional regulation in mouse embryonic stem cells. Genes \& Development. 2011; 25:679-684. [PubMed: 21460036] 


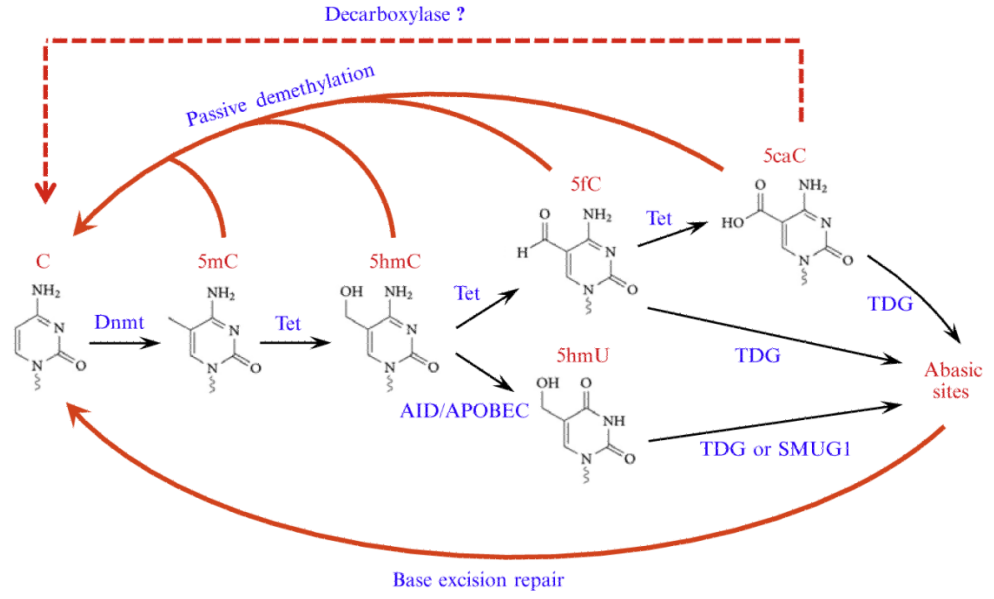

Figure 5.1.

Proposed models of Tet-initiated DNA demethylation pathways. DNA methylation $(5 \mathrm{mC})$ is established and maintained by DNA methyltransferases (Dnmt). In mammals, $5 \mathrm{mC}$ can be oxidized by the Tet proteins to generate $5 \mathrm{hmC}, 5 \mathrm{fC}$, and $5 \mathrm{caC}$. These $5 \mathrm{mC}$ derivatives, specifically $5 \mathrm{fC}$ and $5 \mathrm{caC}$, can be actively removed through base excision repair initiated by the glycosylase TDG or can be passively removed through replication-dependent dilution during preimplantation development. $5 \mathrm{hmC}$ may also be deaminated by AID/APOBEC into $5 \mathrm{hmU}$, which can be removed by TDG or SMUG1. In addition, a putative decarboxylase may directly convert $5 \mathrm{caC}$ to $\mathrm{C}$. 


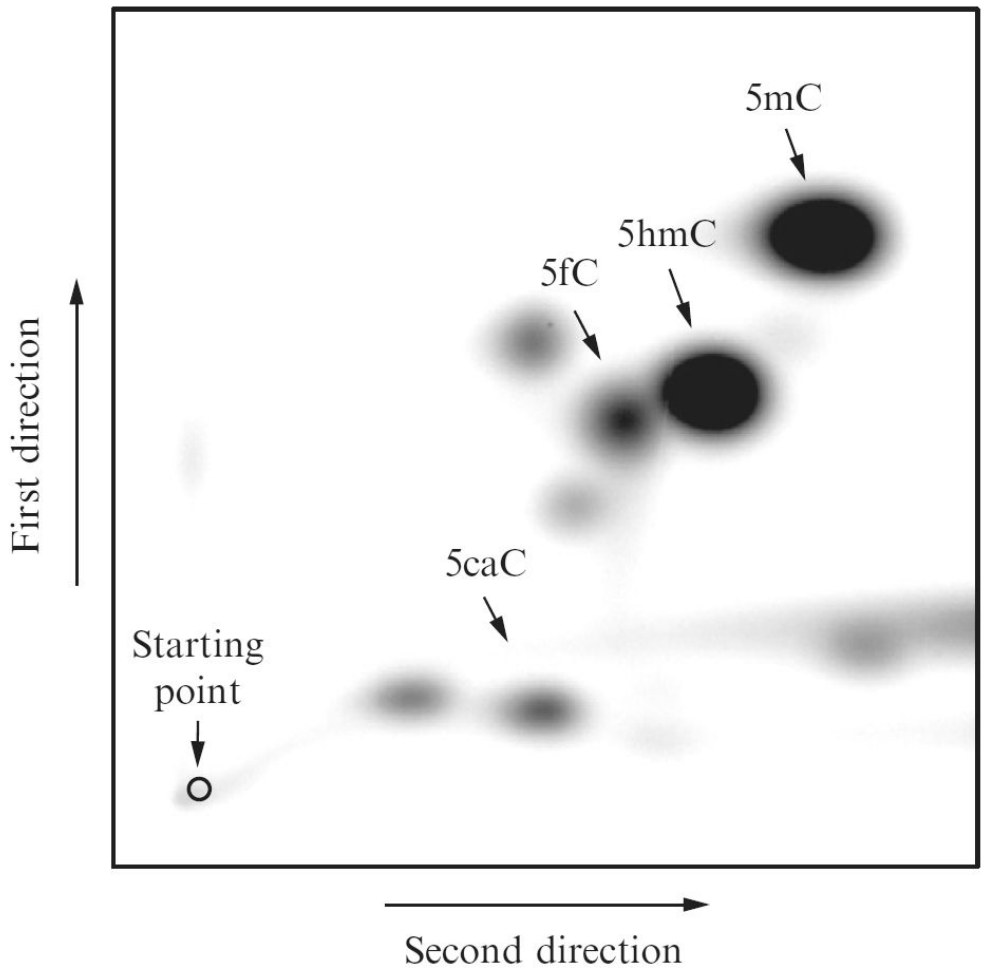

Figure 5.2.

A representative autoradiograph of 2D-TLC analysis of the enzymatic reaction product derived from $5 \mathrm{mC}$-containing 20 -mer oligo DNA incubated with Tet 2 protein. 
A

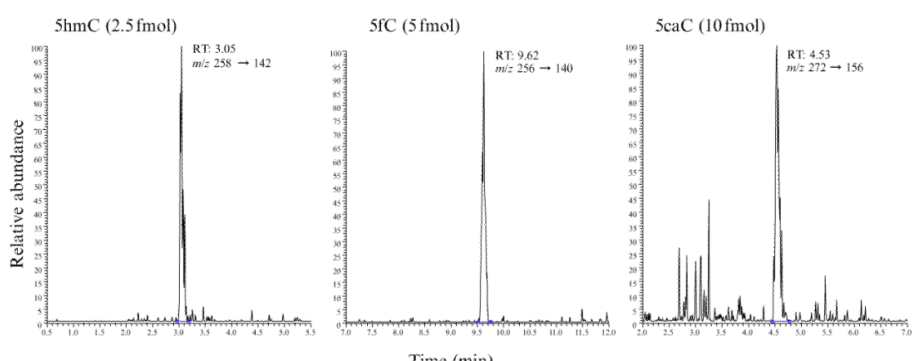

B

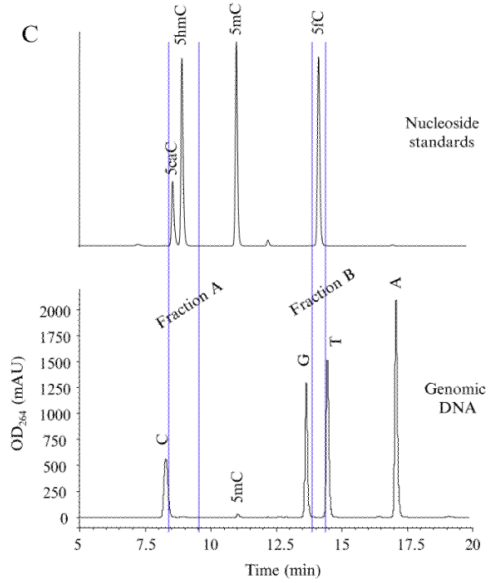

Figure 5.3.

Analysis of the cytosine derivatives using mass spectrometry. (A) Representative LC-MS/ MS chromatograms at the limits of detection for $5 \mathrm{hmC}(2.5 \mathrm{fmol}), 5 \mathrm{fC}(5 \mathrm{fmol})$, and $5 \mathrm{caC}$ (10 fmol), showing excellent signal-to-noise ratio. (B) Schematic representation of the procedures used to quantify endogenous cytosine derivatives in genomic DNA. (C) HPLC analysis of nucleoside standards (top panel) and hydrolyzed genomic DNA. The fractions corresponding to the retention time of $5 \mathrm{hmC} / 5 \mathrm{caC}$ (fraction $\mathrm{A}$ ) and $5 \mathrm{fC}$ (fraction $\mathrm{B}$ ) are collected for further LC-MS/MS analysis. 
Table 5.1

MRM transition parameters for monitoring cytosine and its derivatives

\begin{tabular}{lcc} 
Nucleoside & Transition $(\boldsymbol{m} / z)$ & Collision energy $(\mathbf{e V})$ \\
\hline $\mathrm{C}$ & $228 \rightarrow 112$ & 15 \\
\hline $5 \mathrm{mC}$ & $242 \rightarrow 126$ & 15 \\
\hline $5 \mathrm{hmC}$ & $258 \rightarrow 142$ & 15 \\
\hline $5 \mathrm{fC}$ & $256 \rightarrow 140$ & 15 \\
\hline $5 \mathrm{caC}$ & $272 \rightarrow 156$ & 15 \\
\hline
\end{tabular}


Table 5.2

Electrospray parameters for the mass spectrometer

\begin{tabular}{lc} 
ESI mode & Positive \\
\hline Spray voltage & $3000 \mathrm{~V}$ \\
\hline Vaporizer temperature & $250^{\circ} \mathrm{C}$ \\
\hline Capillary temperature & $285^{\circ} \mathrm{C}$ \\
\hline Sheath gas flow rate & 35 arb \\
\hline AUX gas flow rate & 25 arb \\
\hline
\end{tabular}

